\title{
ATLANTIC RICHFIELD HANFORD COMPANY SEMIANNUAL REPORT \\ BB PROCESS DEVELOPMENT \\ NOVEMBER 1, 1973 THROUGH APRIL 30, 1974
}

Edited by R. D. Fox

Research Department Research and Engineering Division

MARCH 1975

\section{ATLANTIC RICHFIELD HANFORD COMPANY RICHLAND, WASHINGTON 99352}
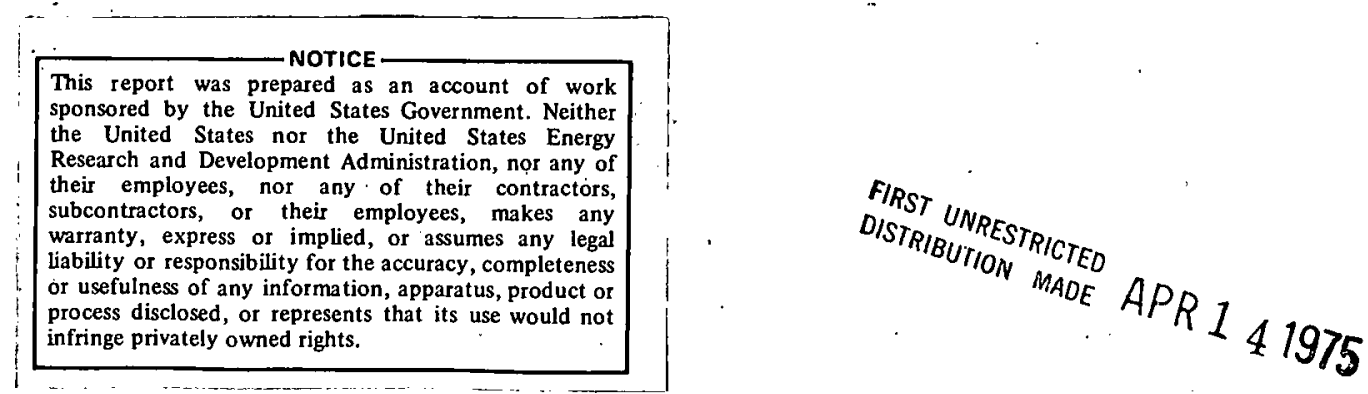


\section{DISCLAIMER}

This report was prepared as an account of work sponsored by an agency of the United States Government. Neither the United States Government nor any agency Thereof, nor any of their employees, makes any warranty, express or implied, or assumes any legal liability or responsibility for the accuracy, completeness, or usefulness of any information, apparatus, product, or process disclosed, or represents that its use would not infringe privately owned rights. Reference herein to any specific commercial product, process, or service by trade name, trademark, manufacturer, or otherwise does not necessarily constitute or imply its endorsement, recommendation, or favoring by the United States Government or any agency thereof. The views and opinions of authors expressed herein do not necessarily state or reflect those of the United States Government or any agency thereof. 


\section{DISCLAIMER}

Portions of this document may be illegible in electronic image products. Images are produced from the best available original document. 
TABLE OF CONTENTS

$\underline{\text { Page }}$

ABSTRACT ............................... $i{ }_{i}$

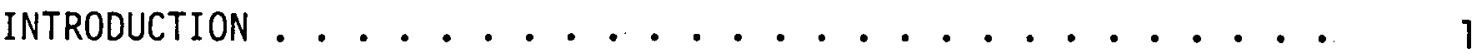

SUMMARY AND MILESTONES. . . . . . . . . . . . . . . . 2

PLUTONIUM PRODUCTION ............................ 11

PLUTONIUM SCRAP PROCESSING. . . . . . . . . . 11

Plutonium 0xide Dissolution. ........... 11

Leaching Plutonium from Soi $\ldots . . . . . . . .13$

Fused Salt Alternatives............ 15

Radiolys is Resistant Solvent .......... 18

Amine Solvent Extraction of Plutonium. . . . . . 20

Disposal of Waste Organic Solvent. ........ 23

Anion Exchange Recovery of Plutonium from

Contaminated Soil. . . . . . . . 25

WASTE MANAGEMENT . . . . . . . . . . . . . . 28

SOLIDIFICATION AND ENCAPSULATION. . . . . . . . 28

Concentration of Nonboiling Wastes........ 28

Solidification with Phosphoric Acid. . . . . . . . . 30

Solidification by the Aqueous Silicate Process . . . . 32

Characterization of Waste Tank Salt Cake ...... 35

PIUBLIC PROTECTION ASSURANCE . . . . . . . . . . . 37

Waste Cleanup and/or Immobilization. . . . . . 37

Migration of Radioactivity into BC Crib Soil.... . 40

Nondestructive Measurement Instrumentation. ..... 42

Environmental Instrumentation. .......... 46

Waste Characterization ........... 51

WASTE TANK LEAK DETECTION AND PREVENTION. . . . . . 57

Waste Tank Liquid Leve1 Monitoring Systems . . . . 57

Waste Tank Integrity........... 61 


\section{ABSTRACT}

This document represents the first in a series of documents which will report on a semiannual basis the activities supported by BB Process Development funds. These research and development activities have the goal of improving the performance of the plutonium processing and waste management programs being operated by Atlantic Richfield Hanford Company. 
ARH-ST-118 A

\author{
ATLANTIC RICHFIELD HANFORD COMPANY \\ SEMIANNUAL REPORT \\ BB PROCESS DEVELOPMENT \\ NOVÉMBER 1, 1973 THROUGH APRIL 30, 1974
}

\title{
INTRODUCTION
}

This document presents statements of the objectives, prior work, current accomplishments, evaluation, and future plans for the various tasks as identified in the U. S. Atomic Energy Commission's Division of Production and Materia 1 Management process development 189 programs.

Two general areas of work are identified: Plutonium Production and Waste Management. Within each of the general areas there is one or more 189 program which has been subdivided into various tasks. The "Project Managers" listed at the beginning of each task are those persons with budgetary responsibility, while those listed as "Principal Investigators" are responsible for project technical direction, evaluation, and reporting.

A key statement about each task, the current accomplished milestones, and the milestone for the next report period are presented at the beginning of the report in the section titled "Summary and Milestones." 


\section{2}

SLMMARY AND MILESTONES

PLUTONIUM PRODUCTION

- Plutonium Oxide. Dissolution

Page 11

Dissolution rates of $\mathrm{PuO}_{2}$ in nitric-hydrofluoric $\left(\mathrm{HNO}_{3}-\mathrm{HF}\right)$ mixtures increase significantly with increasing $\mathrm{HNO}_{3}$ concentration.

Milestone: This program was deferred in order to furnish manpower for the aqueous silicate program.

Milestone for Next Period: Rate constants will be calculated for all dissolution experiments performed thus far and a report summarizing. the results of this work will be completed.

- Leaching Plutonium from Soil

Page 13

Plutonium in 2-9 trench soil is associated primarily with soil particles with diameters of 100 micrometers or less; at $100^{\circ} \mathrm{C}$ a 12 molar $\mathrm{HNO}_{3}-0$. IM HF leachant readily removes about 90 percent of the plutonium on such fines.

Milestone: A new and improved $\mathrm{HNO}_{3}-\mathrm{HF}$ leaching process for removing plutonium from Z-9 trench soil was devised and tested. Milestone for Next Period: Operating parameters for leaching of plutonium from Z-9 trench soil fines by $\mathrm{HNO}_{3}-\mathrm{HF}$ will be defined.

- Fused Salt Alternatives

Page 15

Molten salt fusion tests indicated that the amount of salt required to recover plutonium from incinerator ash was dependent on incinerator feed and operating conditions. A hydroxylamine nitrate scrubbing solution removed 99 percent of the $\mathrm{NO}_{2}$ from the process off-gas stream. 


\section{SUMMARY AND MILESTONES (Contd)}

Fused Salt Alternatives (Contd)

Milestone: Off-gas tests were completed.

Milestone for Next Period: Percent plutonium recovery as a function of solids-to-salt ratio for acid-leached incinerator ash and other "processed" salts will be investigated.

- Radiolysis Resistant Solvent

Page 18

Mixer-settler tests show that workable Pu(IV) extraction flowsheets which employ radiolysis-resistant tributyl phosphate (TBP)-trichlorobenzene (TCB) solvents can be devised.

Milestone: Flowsheet tests with 20 percent TBP-TCB solvents were completed.

Milestone for Next Period: Countercurrent flowsheet tests with both TBP-TCB and TBP-trichloroethylene solvents will be performed.

- Amine Solvent Extraction of Plutonium

Page 20

Performance of a conceptual reflux amine plutonium recovery process is significantly improved by operation at $50^{\circ} \mathrm{C}$ rather than at $25^{\circ} \mathrm{C}$. Milestone: Kinetics of plutonium extraction and stripping by Amberlite LA- $2^{B}$ (trade name, Rohm and Haas Company) solvents were measured at $25^{\circ}$ and $50^{\circ} \mathrm{C}$.

Milestone for Next Period: Complete laboratory-scale continuous countercurrent tests of new and improved reflux amine flowsheets will be conducted. 
SUMMARY AND MILESTONES (Contd)

\section{PLUTONIUM PRODUCTION (Contd)}

- Disposal of Waste Organic Solvent Page 23

Routing of spent Plutonium Reclamation Facility $\mathrm{TBP}^{-\mathrm{CCl}_{4}}$ solvent to the 242-T evaporator is being investigated as a convenient way of disposing of such waste organic material.

Milestone: Commercial surfactants capable of producing stable emulsions of $\mathrm{TBP}^{-\mathrm{CCl}_{4}}$ solvent in high salt aqueous waste solutions were found.

Milestone for Next Period: ' Complete laboratory-scale evaluations will be made of the feasibility and safety of disposing of waste $\mathrm{TBP}-\mathrm{CCl}_{4}$ solvent through the 242-T evaporator system.

- Anion Exchange Recovery of Plutonium from Contaminated Soil Page. 25 Although technically feasible, ion-exchange recovery and purification of plutonium from crib soil leach liquors is not an attractive alternative to solvent extraction processing of such feedstock. Milestone: The capacity of weak and strong base resins for sorbing plutonium from Z-9 trench soil leach liquor was determined.

Milestone for Next Period: A final report will be prepared and issued. 


\section{SUMMARY AND MILESTONES (Contd)}

\section{WASTE MANAGEMENT}

- Concentration of Nonboiling Wastes

Partial neutralization of recycle liquor with nitric acid and subsequent evaporation reduces its volume while producing nonhygroscopic solids from which the interstitial liquor can be readily drained.

Milestone: The composition of solids and recycle liquor produced in the 242-S evaporator was determined.

Milestone for Next Period: The extent to which partially neutralized liquors can be concentrated will be determined.

- Solidification with Phosphoric Acid

Page 30

Slurries of In-tank Solidification recycle liquor and solids formed by addition of phosphoric acid to such liquor when held at $60^{\circ} \mathrm{C}$ for three to seven days, conditions likely to prevail in a phosphatesolids receiver tank, do not solidify completely when cooled to about $25^{\circ} \mathrm{C}$.

Milestone: Recycle liquors cannot be satisfactorily solidified by addition of phosphoric acid.

Milestone for Next Period: This program was discontinued.

- Solidification by the Aqueous Silicate Process

Solid products formed by reactions of commercial clays with recycle liquor were evaluated for hardness, $\mathrm{pH}$, volume increase on mixing, and percent liquid not sorbed by the product; the aqueous 
SUMMARY AND MILESTONES (contd) : :

Solidification by the Aqueous Silicate Process (Contd)

Page 32

silicate process is a viable scheme for solidification of recycle 1iquor.

Milestone: Conditions for a prototype demonstration of the aqueous silicate process were established.

Milestone for Next Period: Radiation stability, leach rates of massive samples, and the heat of formation of aqueous silicate process products will be determined.

- Characterization of Waste Tank Salt Cake Page 35 Salt cake core sampling equipment has been redesigned to take longer cores and the existing facility for receiving core samples has been revised to handle the longer cores.

Milestone: Methods for determining the physical properties of salt cake were developed.

Milestone for Next Period: The design of a remote sait core handling hood will be completed and purchase requisitions will be issued.

- Waste Cleanup and/or Immobilization

Page 37

Initial tests on a vacuum system adopted to surficial cleanup showed that this may be a feasible way to remove surficial radioactive contamination. The vacuum system was used successfully in well 
SUMMARY AND MILESTONES (Contd)

Waste Cleanup and/or Immobilization (Contd)

drilling in loose sand. Studies of affixation of contaminated soil with asphaltic and concrete and asphaltic emulsions showed promise.

Milestone: A preliminary grouting test was completed on B Tank Farm soil.

Milestone for Next Period: A report will be issued on the vacuum system prototype.

- Migration of Radioactivity in BC Crib Soil

Page 40

Both ${ }^{137} \mathrm{CS}$ and ${ }^{90} \mathrm{Sr}$ sorbed on surface soil of the BC Crib area are only slightly (5 to 10 percent) water-leachable; approximately 50 percent of the sorbed ${ }^{137} \mathrm{Cs}$ and ${ }^{90} \mathrm{Sr}$ can be moved by extensive leaching with 0.1 M ammonium nitrate solution.

Milestone: Leachability of ${ }^{90} \mathrm{Sr}$ from contaminated $\mathrm{BC}$ Crib soil was determined using various aqueous leaching agents.

Milestone for Next Feriod: Program termirated.

- Nondestructive Measurement Instrumentation

Equipmerit for ARIS-2 (Automatic Radioactive Inventory System) and for the GXDR (Gamma, X-ray Data Reauction) systenı has been designed and ordered; detector components already delivered operate within design specifications.

Milestone: A central data reduction system capable of meeting all requirements for radionuclide inventory and assay has been designed.

Milestone for Next Period: Remaining components of the ARIS-2 and GXDR systems will be calibrated and placed in service. 
SUMMARY AND MILESTONES (Contd)

WASTE MANAGFMENT (Contd)

- Environmental Instrumentation

Page 46

An argon-filled highly sensitive gamma dosimeter proved to be an important asset for characterizing various waste areas. A directional neutron counter and an environmental neutron counter showed feasibility.

Milestone: Equipment for monitoring surficial contamination (DevVan-I) was laboratory-tested.

Milestone for Next Period: Argon Gamma Dosimeter and Neutron Counting System reports will be issued.

- Waste Characterization

Page $: 51$

Nondestructive testing and laboratory assay has helped to characterize such areas as the $B C$ Crib and $U$ Pond. A status review was done on the $B C$ Crib, over 500 environmental determinations were made on the $U$ Pond, and initial chemical and physical property studies were undertaken in both areas. First detonation experiments were carried out on potentially hazardous substances in the salt cäke. A toxicity study was made of all the elements. Initial outside-the-tank leak detection tests were conducted using two concepts, conductivity and impedance measurements, and results were satisfactory in an idealized test site.

Milestone: Automatic air sampling equipment was installed at $U$ Area and BC Area.

Milestone for Next Period: The Z-9 neutron characterization report wil1 be issued. 


\section{WASTE MANAGEMENT (Contd)}

- Waste Tank Liquid Level Monitoring Systems

Page 57

An engineering audit of the present liquid level measurement system and data transmission system was completed and documented. Two liquid level measurement systems, one based on radiofrequency and the other on ultrasonic frequency, were evaluated in the laboratory as potential alternatives to the existing liquid level measurement sys tem.

Milestone: An engineering audit was completed and a decision made to prototype two laboratory liquid level measurement systems.

Milestone for Next Period: Radio- and ul trasonic-frequency prototypes will be installed in a tank for a performance evaluation.

- Waste Tank Integrity

Page 61

Test results indicate that localized concentration cells should not be a cause of premature failure of waste tank liners. The effectiveness of nitrite in reducing the rate of attack on carbon steel was found to be both concentration- and temperature-dependent. The minimum current density to cathodically protect mild-steel specimens lies between 5 and 10 milliamperes per square foot. An ultrasonic needle probe was developed that can locate cracks which fully penetrate waste tank walls.

Milestone: The minimum current to cathodically protect mild-steel specimens in contact with simulated tank waste was determined and an ultrasonic needle probe was developed that can locate cracks which fully penetrate tank walls.

Milestone for Next Period: The work on cathodic protection will be completed. 


\section{PLUTONIUM PRODUCTION}

\section{PLUTONIUM SCRAP PROCESSING}

Plutonium Oxide Dissolution

Project Managers: $\quad$ M. H. Campbell

R. E. Felt

Principal Investigator: G. S. Barney

Objective and Scope

This work will furnish a better understanding of the dissolution behavior of plutonium dioxide $\left(\mathrm{PuO}_{2}\right)$ in nitric-hydrofluoric acid mixtures, knowledge which will be used to improve the recovery of plutoni um from scrap.

Prior Work

A rate law, developed for the dissolution of powdered $\mathrm{PuO}_{2}$ in nitric-hydrofluoric acid mixtures, which can be applied over the entire range of dissolution, is given by the equation

$$
\frac{d[\mathrm{Pu}]_{t}}{d t}=k_{T} S[\mathrm{HF}]_{f}
$$

where $k_{1}$ is the rate constant, $S$ is the surface area of the $\mathrm{PuO}_{2}$, $[\mathrm{HF}]_{f}$ is the concentration of free (noncomplexed) hydrofluoric acid, and $[\mathrm{Pu}]_{t}$ is the total plutonium concentration (complexed and noncomplexed). This rate law implies a dissolution mechanism in which the rate-controlling step is attack of the $\mathrm{PuO}_{2}$ surface by undissociated HF. The rapid decrease in dissolution rate with time is due to the removal of free $\mathrm{HF}$ from solution through the formation of $\mathrm{PuF}_{\mathrm{X}}+(4-\mathrm{x})$ complexes as the $\mathrm{PuO}_{2}$ is dissolved. 


\section{PLUTONIUM PRODUCTION (Contd)}

Plutonium Oxide Dissolution (Contd)

\section{Progress During Report Period}

Additional dissolution experiments at $100^{\circ} \mathrm{C}$ were completed using solvents with compositions similar to that of plant dissolver solution (nominal 12M-0.34M HF). Nitric acid concentration was varied from 10 to $15.8 \mathrm{M}$ and $\mathrm{HF}$ concentration from 0.29 to $0.34 \mathrm{M}$. The use of concentrated (15.8M) $\mathrm{HNO}_{3}$ increased the dissolution rate significantly compared to a $10 \mathrm{M} \mathrm{HNO}_{3}$ solvent (both $0.34 \mathrm{M}$ in $\mathrm{HF}$ ). Ninety percent dissolution was achieved after only 60 minutes with a $15.8 \mathrm{M} \mathrm{HNO}_{3}-0.34 \mathrm{M} \mathrm{HF}$ dissolvent; with a $10 \mathrm{M} \mathrm{HNO}_{3}-0.34 \mathrm{M}$ HF dissolvent, total dissolution required about 150 minutes.

\section{Evaluation of Effort}

A rate 1 aw and mechanism for the complete range of dissolution conditions have been obtained. These show the importance of maintaining a high concentration of free (noncomplexed) $\mathrm{HF}$ in the solvent in order to speed the dissolution. The use of concentrated $(15.8 \mathrm{M}) \mathrm{HNO}_{3}$ also helps increase the dissolution rate. This information will provide a basis for correctly designing dissolution flowsheets.

Future Work

Rate constants will be evaluated for all the dissolution experiments performed thus far. The dissolution rate for $\mathrm{PuO}_{2}$ obtained from various sources will be measured. 


\section{PLUTONIUM PRODUCTION (Contd)}

\section{Leaching Plutonium From Soil}

Project Managers:

Principal Investigators:
M. H. Campbe 11

R. E. Felt

D. A. Dodd

P. C. Ely

V. L. Schuelein

Objective and Scope

The purpose of this study is to provide data to support flowsheets for the future mining and processing of Z-9 covered trench soil for reclamation of plutonium.

Prior Work

Studies of $\mathrm{HNO}_{3}-\mathrm{HF}$ leaching of $\mathrm{Z}-9$ covered trench soil indicated plutonium exists in three forms in such soil: particulate oxide, tightly bound ion-exchanged species, and material adsorbed in cracks and fissures of chemically decomposed sand and soil. The bulk of the plutonium in the soil is in the top 15 centimeters of the trench. Generally, $\mathrm{HNO}_{3}-\mathrm{HF}$ solutions leach 70 to 80 percent of the plutonium with the bulk of the remaining.plutonium associated with fines.

\section{Progress During Report Period}

Development of suitable leach flowsheets was hindered by the unavailability of Z-9 trench soil samples throughout most of the report period. The leach flowsheet currently favored involves preliminary wet screening of the mined soil to separate fine material (<100 micrometers diameter) from the larger particles. The fine material containing about 90 percent of the plutonium is first washed with $6 \mathrm{M} \mathrm{HNO}_{3}$ and then batch-leached at $100^{\circ} \mathrm{C}$ with a $12 \mathrm{M} \mathrm{HNO}_{3}$ 0 . IM HF solution at a ratio of one 1 iter of solvent per 100-200 grams of soil. (The nitric acid prewash is included to remove materials which compete with plutonium for fluoride in the $\mathrm{HNO}_{3}-\mathrm{HF}$ leachant.) 


\section{PLUTONIUM PRODUCTION (Contd)}

\section{Leaching Plutonium From Soil (Contd)}

This flowsheet approach minimizes the amount of soil which must be leached while producing a leachate relatively concentrated in plutonium. In one successful demonstration of this flowsheet, a leachate containing about one gram per liter plutonium was obtained after only an hour of leaching.

A cadmi um nitrate solution was recently added to the Z-9 trench for additional criticality control. Leaching tests of soil subsequently taken from the trench were made to establish the cadmium profile in the top 61 centimeters of the trench. These leaching tes ts showed a maximum concentration of $1.40 \times 10^{-4}$ grams $C d$ per gram of soil in the top $1.2 \mathrm{~cm}$ quite evenly distributed down to $4.6 \times 10^{-7}$ grams Cd per gram of soil at the $45-$ and $64-\mathrm{cm}$ levels.

\section{Evaluation of Effort}

A new and improved leaching process for removal of plutonium from crib soils was devised; preliminary tests indicate its feasibility. The cadmium profile in the recently poisoned Z-9 trench was measured.

\section{Future Work}

Present plans for removal of Pu-contaminated soil from the Z-9 trench call for storage, without leaching, of the excavated material. Laboratory-scale development and demonstration of leaching flowsheets will be continued, however, to provide needed technology in the event a decision is later made to recover plutonium from the Z-9 trench soil. Development of an efficient low-volume process for leaching fines will be emphasized in the next report period. 
PLUTONIUM PRODUCTION (Contd)

Fused Salt Alternatives

$\begin{array}{ll}\text { Project Managers: } & \text { M. H. Campbell } \\ & \text { H. H. Van Tuyl (BNW) } \\ \text { Principal Investigators: } & \text { R. E. Felt } \\ & \text { E. J. Wheelwright (BNW) } \\ & \text { J. A. Partridge (BNW). }\end{array}$

Objective and Scope

This project has three objectives: (1) to determine the feasibility of decomposing radioactively contaminated combustible waste in a low-pressure molten salt system; (2) to develop an effective process to recover plutonium from existing incinerator ash, acid-leach ash, other "processed solids," and any residues of the molten salt process; and (3) to test the removal of $\mathrm{NO}_{2}$ from dissolver off-gas by means of hydroxylamine nitrate:

The processes will be demonstrated on the laboratory scale.

\section{Prior Work}

Two processes for the decomposition of carbonaceous waste materials in molten salt system were investigated: direct combustion in a supply of oxygen and pyrolysis in the absence of oxygen. At operating temperatures of 500 to $800^{\circ} \mathrm{C}$, a $\mathrm{KNO}_{3}-\mathrm{NaNO}_{3}$ salt proved satisfactory as an "oxidizing" salt and $\mathrm{K}_{2} \mathrm{CO}_{3}-\mathrm{Li}_{2} \mathrm{CO}_{3}-\mathrm{NaNO}_{3}$ was found to be a satisfactory "inert" salt (pyrolysis mode). The decomposition of an amount of simulated carbonaceous waste, equal in weight to the weight of the carbonate salt, was demonstrated using the pyrolysis/ oxidation cycles.

Plutonium recoveries of 95 percent or greater from one can of regular ash were demonstrated in fusion tests with ash-to-salt weight ratios as high as $2: 7$. In each of the tests, the salt mixture 


\section{PLUTONIUM PRODUCTION. (Contd)}

\section{Fused Salt Alternatives (Contd)}

contained equal amounts (by weight) of sodium hydroxide and sodium peroxide. The fused mixture was maintained at 600 to $650^{\circ} \mathrm{C}$ for one hour in a 2-inch diameter by 4 -inch long mild-steel can. The me1t was stirred with an air sparge to prevent localized corrosion of the can. After the can and contents were cool, they were dissolved in nitric acid and the solution and residual solids were analyzed for plutonium.

\section{Progress During Report Period}

Peroxide fusion tests conducted with a second can of incinerator ash resulted in a significantly reduced plutonium recovery. For example, at $1: 7$ and $2: 7$ weight ratios of ash-to-salt, on $1 y$ percent and 74 percent, respectively, of the plutonium was solubilized upon dissolution as compared to 95 percent previously obtained for an ash-to-salt ratio of $2: 7$. At a $3: 7$ ash-to-salt weight ratio, only 43 to 48 percent plutonium recovery was achieved with ash from the second can.

A re-work test was performed with some of the residual solids from two fusion tests conducted at ash-to-salt ratios of $3: 7$. The re-work test was at a solids-to-salt weight ratio of $1: 7$ and resulted in solubilization of 80 percent of the plutonium which had remained on the residual solids from the former tests.

A series of $\mathrm{NO}_{2}$ scrubbing tests were completed which demonstrated that aqueous hydroxylamine nitrate can be used successfully to remove $\mathrm{NO}_{2}$ from an air stream. Experiments were conducted with a 1.5-inch inside diameter packed column (packed to a height of 34 inches with 6-millimeter glass beads) containing 31 to 33 inches of aqueous solution flowing countercurrent to the air stream. 


\section{PLUTONIUM PRODUCTION (Contd)}

\section{Fused Salt Alternatives (Contd)}

Greater than 99 percent removal of $\mathrm{NO}_{2}$ from air containing 12,000 parts per million $\mathrm{NO}_{2}$ was obtained at an air flow rate of 2,000 milliliters per minute and an aqueous flow rate of 1 milliliter per minute. The aqueous scrub solution, 0.41 molar hydroxylamine nitrate0.090 molar nitric acid, reduced the $\mathrm{NO}_{2}$ concentration below the detection limit of 100 parts per million. A run made under identical conditions, except that the aqueous scrub was $0.90 \mathrm{M}$ - nitric acid, results in orily 89 to 90 percent $\mathrm{NO}_{2}$ removal.

\section{Evaluation of Effort}

The small ash-to-salt ratio required to recover plutonium from standard ash is not encouraging if waste volume is an important consideration. The process does have promise for small volumes of scrap not amenable to other methods of processing.

\section{Future Work}

Application of peroxide fusion for recovery of plutonium from "processed" solids will be investigated and flowsheet development work will be performed. 


\section{PLUTONIUM PRODUCTION (Contd)}

Radiolysis-Resistant Solvents

Project Managers:

R. E. Felt

M. H. Campbe11

Principal Investigators:

G. S. Barney

D. G. Bouse

Objective and Scope

The objective is to develop a solvent composition for plutonium extraction that is more resistant to radiolysis than the presently used tributyl phosphate (TBP)-carbon tetrachloride $\left(\mathrm{CCl}_{4}\right)$ extractant.

Prior Work

Aromatic halides and chloroethylene compounds used as diluents for TBP protect the TBP from radiolytic degradation to dibuty 1 phosphoric acid (DBP) and monobuty phosphoric acid (MBP). These diluents are also more resistant than $\mathrm{CCl}_{4}$ to formation of free chloride ion which causes corrosion problems in the Plutonium Reclamation Facility. Relevant physical and chemical properties of the pure diluents and 20 percent TBP-diluent mixtures were determined. of the diluents tested, trichlorobenzene (TCB) and tetrachloroethylene have the most acceptable physical properties. Distribution coefficients for Pu(IV) are somewhat higher for TBP-tetrachloroethylene solvents than for TBP-TCB extractants.

\section{Progress During Report Period}

Flowsheet tests using TCB as a diluent for TBP confirmed earlier findings that $\mathrm{PU}(\mathrm{IV})$ extraction coefficients for the 20 percent TBP$T C B$ solvent are lower than those for 20 percent $\mathrm{TBP}_{-} \mathrm{CCl}_{4}$. However, workable flowsheets can be developed using TCB. as a diluent. Physical operation of the mixer-settlers used in these tests was excellent. 


\section{PLUTONIUM PRODUCTION (Contd)}

\section{Radiolysis-Resistant Solvents (Contd).}

The advantage of the lower volatility of TCB over $\mathrm{CCl}_{4}$ becomes more significant when considering flowsheets which benefit from operation at elevated temperature.

The effect of nitrous acid on the radiolysis and hydrolysis of TBP was found to be negligible; plutonium retention values were the same with or without the presence of nitrous acid in the organic phase. Chemical degradation of TBP at room temperature is not significant compared to radiolytic degradation.

\section{Evaluation of Effort}

Several diluents which offer much greater protection from radiolysis of TBP than the presently used $\mathrm{CCl}_{4}$ have been found. These diluents also produce less chloride from radiolysis; hence, corrosion rates of process vessels would decrease if these diluents were substituted for $\mathrm{CCl}_{4}$.

Mixer-settler tests show that workable flowsheets can be developed using TCB as a diluent.

Future Work

Additional flowsheet tests of the new diluents will be made in the laboratory using mixer-settlers and/or pulse columns. Plutonium (IV) extraction coefficients for the 20 percent TBP-tetrachloroethylene solvent will be measured. 


\title{
PLUTONIUM PRODUCTION (Contd)
}

\section{Amine Solvent Extraction of Plutonium}

\author{
Project Managers: $\quad$ R. E. Felt \\ M. H. Campbe11 \\ Principal Investigators: W. W. Schulz \\ D. G. Bouse
}

Objective and Scope

The objective is to improve solvent extraction performance in the Plutonium Reclamation Facility while decreasing costs by developing an amine plutonium extraction process to replace the currently used TBP process.

Prior Work

A revised and simplified conceptual plutonium recovery process flowsheet was devised which employs Amberlite LA- $B$, a high-molecular weight secondary amine commercially available from the Rohm and Haas Company, as the extractant. The new process flowsheet, which involves operation of only the CA (extraction), CC (strip), and CO (solvent wash) columns, was satisfactorily demonstrated in mixersettler runs employing both 30 percent $\mathrm{LA}-2-\mathrm{CCl}_{4}$ and 30 percent LA-2-TCB extractants. An $\mathrm{HNO}_{3}$-HF solution is used in the solvent wash column to remove small amounts of plutonium not stripped in the $C C$ column.

Extensive solvent quality tests demonstrated that the chemical and radiolytic stability of the LA-2 extractant under proposed flowsheet conditions is superior to that of the presently. used 20 percent $\mathrm{TBP}-\mathrm{CCl}_{4}$ solvent. For example, after exhaustive stripping with dilute $\mathrm{HNO}_{3}$ an irradiated LA-2 solvent retains only about 0.3 milligrams Pu per liter for each watt-hour of absorbed energy compared with. retention of $56 \mathrm{mg}$ Pu/liter by an irradiated, stripped 20 percent $\mathrm{TBP}_{-} \mathrm{CCl}_{4}$ solvent. At expected maximum solvent irradiation doses 


\section{PLUTONIUMM PRODUCTION (Contd)}

Amine Solvent Extraction of Plutonium (Contd)

(20 to 40 watt-hour per .1iter), the adverse effects of the LA-2 degradation products can be largely overcome by periodic washing with $\mathrm{HNO}_{3}-\mathrm{HF}$ solution. Amberlite LA-2 solutions are not degraded by $3 \mathrm{HNO}_{3}-0.025 \mathrm{M} \mathrm{HNO}_{2}$ solutions even when exposed to such solutions for as long as four weeks at either 25 or $40^{\circ} \mathrm{C}$.

\section{Progress During Report Period}

Further batch and mixer-settler tests of the reflux amine plutonium recovery flowsheet showed that process performance is significantly enhanced by operation at $50^{\circ} \mathrm{C}$ rather than at $25^{\circ} \mathrm{C}$. At $25^{\circ} \mathrm{C} 30$ percent $\mathrm{LA}-2$ solvents extract $\mathrm{Pu}(\mathrm{IV})$ from $\mathrm{HNO}_{3}-\mathrm{Al}\left(\mathrm{NO}_{3}\right)_{3}$ solutions more slow'y than do 20 percent iBF extractiants; at $50^{\circ} \mathrm{C}$, however, a 30 percent LA-2-TCB solvent extracts $\mathrm{Pu}$ (IV) about as fast as do TBP solvents at $25^{\circ} \mathrm{C}$. Operation at $50^{\circ} \mathrm{C}$ also benefits strip column (CC column) performance by increasing disproportionation of $\mathrm{Pu}(\mathrm{IV})$ to inextractable $\mathrm{Pu}$ (III) and Pu(V) which occurs in low-acid solutions; equilibrium distribution ratios for $\mathrm{Pu}(\mathrm{IV})$ at $50^{\circ} \mathrm{C}$ under strip column conditions are about threefold lower than at $25^{\circ} \mathrm{C}$.

Mixer-settler flowsheet tests confirmed the beneficial effects of increased temperature upon performance of the amine process flowsheet. Thus, using a 35 percent LA-2-TCB extractant and 12 mixer-settler stages, plutonium losses in the extraction (CA column) were 9.0 and 1.2 percent at 25 and $50^{\circ} \mathrm{C}$, respectively. Improvements in $\mathrm{CC}$ column performance were also observed, at $25^{\circ} \mathrm{C}$, the plutonium loss to the organic waste stream was 5.6 percent while at $50^{\circ} \mathrm{C}$ only 2.7 percent of the plutonium was unstripped. Extensive equilibrium data for distribution of $\mathrm{HNO}_{3}$, plutonium, and thorium between 30 and 40 percent LA-2 TCB solvents at both 25 and $50^{\circ} \mathrm{C}$ were obtained. 


\section{PLUTONIUM PRODUCTION (Contd)}

\section{Amine Solvent Extraction of Plutonium (Contd)}

At $\mathrm{HNO}_{3}$ concentrations above about $1.0 \mathrm{M}$ plutonium extraction at $50^{\circ} \mathrm{C}$ is nearly identical to that at $25^{\circ} \mathrm{C}$. Separation factors $(\alpha=$ distribution ratio for Pu/distribution ratio for Th) for partition of plutoni um and thorium range from about 250 at $1.0 \mathrm{M} \mathrm{HNO}$ to about 100 at 4. $\mathrm{O} \mathrm{HNO}_{3}$. These values indicate the reflux amine flowsheet can be used satisfactorily to process feeds derived from Pu-Th scrap.

\section{Evaluation of Effort}

Additional batch and mixer-settler tests of the conceptual three-column reflux amine process have shown this to be a workable scheme for use in the Plutonium Reclamation Facility. Because radiolysis products of LA-2 complex plutonium much less strongly than do those of TBP, the amine process appears particularly suited to processing high-exposure plutonium scrap containing significant concentrations of ${ }^{240} \mathrm{Pu}$ and $241 \mathrm{Pu}$.

\section{Future Work}

Applicability of improved $\left(50^{\circ} \mathrm{C}\right)$ reflux amine flowsheets for recovery and purification of plutonium from Pu-U and Pu-Th as well as Pu-only scrap will be tested and demonstrated in further mixersettler tests. Supporting equilibrium data for distribution of uranium, thorium, and various metallic impurities between LA-2 TCB solvents and aqueous $\mathrm{HNO}_{3}-\mathrm{Al}\left(\mathrm{NO}_{3}\right)_{3}$ - $\mathrm{HF}$ solutions will be collected. Physical properties (e.g., viscosity, specific gravity, etc.) of LA-2-TCB solvents will also be determined. 


\section{PLUTONIUM PRODUCTION. (Contd)}

Disposal of Waste Organic Solvents

Project Managers:

D. G. Harlow

R. E. Felt

Principal Investigators:

D. A. Puryear

D. A. Dodd

D. A. Danch

Objectives and Scope

The goal of this program is to develop technology which will permit safe; economical disposal of spent Plutonium Reclamation Facility TBP and dibutylbutyl phosphonate $(\mathrm{DBBP})-\mathrm{CCl}_{4}$ solvents.

\section{Prior Work}

Tests of a wet oxidation process to oxidize waste solvents from the Hanford Plutonium Reclamation Facility were performed both in Atlantic Richfield Hanford Company laboratories and on contract with ZIMPRO, Inc., a subsidiary of Sterling Drugs. These tests demonstrated that the Zimmerman wet oxidation process will effectively oxidize undiluted TBP at $325^{\circ} \mathrm{C}$ and $2300-2400$ psig.

As expected, solvents containing $\mathrm{CCl}_{4}$ were considerably more difficult to oxidize. Rapid pressurization from the easily volatilized $\mathrm{CCl}_{4}$ was identified as a problem; a potential solution to this problem is to selectively distill the $\mathrm{CCl}_{4}$ prior to controlled wet oxidation of the TBP. The added costs for distillation and handling of a new waste stream, coupled with increased process complexity, are a deterrent to this approach, however.

Progress During Report Period

An alternative method of disposing of spent $\mathrm{TBP}_{-}-\mathrm{CCl}_{4}$ and $\mathrm{DBBP}-\mathrm{CCl}_{4}$ solvents is currently under consideration. In this scheme, a small volume of the organic solvent is mixed with a large 


\section{PLUTONIUM PRODUCTION (Contd)}

\section{Disposal of Waste Organic Solvents (Contd)}

volume of radioactive waste and the resulting mixture (97 volume percent aqueous - three volume percent organic) is evaporated in the 242-T In-Tank Solidification evaporator. Carbon tetrachloride which distills in the evaporator is condensed, collected, and routed to a crib while the slurry of solids and aqueous recycle waste containing TBP and its hydrolysis products is routed to an ITS receiver tank. To guard against possible criticality conditions, it is essential to disperse and suspend the organic solvent in the aqueous phase.

Thirty commercially available surfactants were surveyed for their ability to suspend $\mathrm{TBP}-\mathrm{CCl}_{4}$ solvents in high salt content aqueous wastes. Using one part of surfactant to ten parts of $\mathrm{TBP}_{-} \mathrm{CCl}_{4}$ solvent, four of the surfactants tested achieved a stable (24-48 hour) emulsion of the $\mathrm{TBP}-\mathrm{CCl}_{4}$ solvent in aqueous wastes. These particular reagents are soluble, in both water and $\mathrm{CCl}_{4}$ and are stable in both acid and alkaline media.

Evaluation of Effort

Disposal of spent Plutonium Reclamation Facility $\mathrm{TBP}_{-} \mathrm{CCl}_{4}$ solvents through the 242-T evaporator appears to be a viable process. Stable dispersions of the $\mathrm{TBP}_{-}-\mathrm{CCl}_{4}$ solvent in high salt waste solutions can be achieved by the addition of small amounts of commercially available surfactants.

\section{Future Work}

Further laboratory studies will be made of the feasibility and safety of disposing TBP-CCl 4 solvents to the 242-T evaporator. The use of nitric-sulfuric acid solutions to oxidize spent organic solvents will be investigated. 


\section{PLUTONIUM PRODUCTION (Contd)}

\section{Anion Exchange Recovery of Plutonium from Contaminated Soil}

Project Managers:

M. H. Campbeil

R. E. Felt

Principal Investigator: W. W. Schulz

Objectives and Scope

The objective of this study is to determine the feasibility of anion exchange purification and concentration of plutonium from nitric acid leachates of crib soils, particularly Z-9 Covered Trench soil, and to establish optimum conditions for this process.

Prior Work

Samples of 13 new commercially available resins (ail nominally 20- to 50-mesh) were tested for plutonium and desorption kinetics at $25^{\circ} \mathrm{C}$ (incentives exist for operating this process at $25^{\circ} \mathrm{C}$ in fluidized bed equipment). The two best of the resins, Amberlyst IRA-458 and Amberlite XE-270 (both made by Rohm and Haas Company) showed plutonium sorption and elution rates equal to or greater than that of the Permutit SK resin used for about 15 years in the Hanford Purex plant to purify and concentrate plutonium.

The expected good performance of Amberlyst IRA-458 resin was not borne out in column load tests. For an $0.55 \mathrm{gram} \mathrm{Pu(IV)/1iter}$ feed at $25^{\circ} \mathrm{C}$ and at a given flow rate, the capacity of IRA-458 to 10 percent breakthrough was only 23 percent of that for Permutit SK resin at $60^{\circ} \mathrm{C}$. Load cycle tests of XE-270 resin, a weak-base macroreticular exchanger, were made with $7.5 \mathrm{M} \mathrm{HNO}_{3}-0.5$ grams per liter plutonium feeds prepared from actual 2-9 Trench soil leachate and purified stock reagents. Plutonium recoveries ranged from 93 to 96 percent at flow rates of 0.75 to 0.96 milliliter per square 


\section{PLUTONIUM PRODUCTION (Contd)}

\section{Anion Exchange Recovery of Plutonium from Contaminated Soil (Contd)}

centimeter per minute to only 71 to 70 percent at flow rates of 3.1 $\mathrm{ml} / \mathrm{cm}^{2}$-min. For a given flow rate, plutonium loaded equally well from both Z-9 Trench soil leachate and from feed made from purified reagents.

\section{Progress During Report Period}

Additional column tests were made with both XE-370 and Ionac $A 580^{B}$ (trademark Ionac Chemical Company) anion exchange resins. The latter is a gel-type strong base exchanger recently used in the Purex plant to purify and concentrate plutonium. Runs were made with 7.5M $\mathrm{HNO}_{3}-0.5 \mathrm{~g} / 1 \mathrm{Pu}(\mathrm{IV})$ feeds prepared either from purified stock reagents or by appropriate dilution of an $11.9 \mathrm{M} \mathrm{HNO}-0.3 \mathrm{M} \mathrm{HF}-0.12 \mathrm{~g} / 1$ $\mathrm{Pu}$ solution obtained by leaching of Z-9 Trench soil. With the former feed at a flow rate of about $0.7 \mathrm{ml} / \mathrm{cm}^{2}-\mathrm{min}$. the capacity of $\mathrm{XE}-270$ resin at $25^{\circ} \mathrm{C}$ to 10 percent breakthrough was only one-third to one-half that of the Ionac $A 580$ resin at $60^{\circ} \mathrm{C}$. However, at the same temperature and flow conditions, both resins exhibited about the same capacity for sorbing plutonium from diluted Z-9 Trench soil leach liquor; 10 percent breakthrough with both resins occurred after passage of only 15-20 column volumes of feed corresponding to a resin loading of only about $10 \mathrm{~g} / 1 \mathrm{Pu}$. The decreased capacity of the Ionac strong base resin for sorbing plutonium from the diluted leach liquor is due, it is believed, to the presence of a substantial concentration of anionic plutonium fluoride species which have a much lower affinity for resin sites than does the $\mathrm{Pu}\left(\mathrm{NO}_{3}\right)_{6}{ }^{2-}$ entity.

Elution behavior of the Ionac A580 resin is markedly superior to that of the XE-270 resin. Over 90 percent of the plutonium 


\section{'PLUTONIUM PRODUCTION (Contd)}

\section{Anion Exchange Recovery of Plutonium from Contaminated Soil (Contd)}

loaded on the Ionac A580 resin elutes into a single column volume of $0.25 \mathrm{M} \mathrm{HNO}_{3}$ while considerable tailing occurs during elution of plutoni um from the XE-270 resin.

\section{Evaluation of Effort}

Both macroreticular weak base (e.g., XE-270) and microreticular strong base (e.g., Ionac A580) anion exchange resins can be used to recover and purify plutoni um from $\mathrm{HNO}_{3}$ - $\mathrm{HF}$ leachates of contaminated soil. The limited capacity of these resins for sorbing plutonium from such liquors is a serious deterrent to their use. For this reason ion exchange recovery of plutonium from contaminated soi 1 leachates is not an attractive alternative to solvent extraction processing of such leachates in existing Plutonium Reclamation Facility equipment.

Future Work

Column runs are in progress to determine the performance of Dowex MSA-1, a macroreticular strong-base resin made by the Dow Chemical Company, in sorbing plutonium at $25^{\circ} \mathrm{C}$ from Z-9 Trench soil leach liquor. A terminal report summarizing results of these and other tests will be prepared. No additional experimental work will be done in accordance with the decision to mine and storsi unleached 2.-9 Trench soil. 


\section{WASTE MANAGEMENT}

SOLIDIFICATION AND ENCAPSULATION

Concentration of Nonboiling Wastes

Project Managers:
R. C. Roal
M. H. Campbel1
N. L. Harms
J. S. Buckingham
D. A. Puryear
W. P. Metz

Principal Investigators:

Objectives and Scope

The original goal of this work was to develop schemes for lowering the boiling points of in-tank solidification (ITS) recycle liquors to allow existing in-tank heaters to further concentrate these wastes. The scope has been expanded to include definition of the volume of recycle liquor remaining at the end of the waste solidification program.

Prior Work

During the concentration of nonboiling waste liquors in both atmospheric and vacuum evaporators, concentrations of $\mathrm{NaOH}$ and $\mathrm{NaAlO}_{2}$ increase until either maximum possible concentration of the waste is reached or undesirable solids begin to form. Undesirable solids are those from which interstitial liquor cannot be removed or which are too hygroscopic. Partial neutralization of recycle liquors with either nitric acid or sulfuric acid lowers their boiling points, thus permitting additional concentration. Nitric acid is preferable to sulfuric acid in that greater volume reduction can subsequently be achieved with concomitant production of satisfactory solids. 


\section{WASTE MANAGEMENT (Contd)}

\section{Concentration of Nonboiling Wastes (Contd)}

Progress During Report Period

The compositions of synthetic waste slurries, recycle liquors, and solids associated with recycle liquors expected to be generated at various points in the waste concentration program were determined. The compositions of solid and liquid samples taken from the 242-S vacuum evaporator slurry receiving tanks were measured; of the ${ }^{137} \mathrm{Cs}$ in the slurry, 14 percent was associated with the solids and 86 percent remained in the liquid.

Extremely hygroscopic solids resulted when recycle liquiors were evaporated to dryness in a laboratory-scale vacuum evaporator. In other laboratory work nitric acid was added to synthetic recycle liquor to neutralize about 40 percent of its $\mathrm{NaOH}$ content. Subsequent evaporation in a vacuum evaporator reduced the volume of the partially neutralized waste by about 20 percent and yielded satisfactory salt cake. The volume of the salt cake thus produced was equal to the volume of liquid evaporated.

\section{Evaluation of Effort}

Data which will be useful in defining optimum modes of operation of the 242-S vacuum evaporator were obtained by analyzing solids and associated mother liquor produced during operation of the evaporator with S Tank Farm feeds. The feasibility of achieving some reduction in volume of recycle liquor by partial neutralization with nitric acid and evaporation in a vacuum evaporator was demonstrated.

Future Work

Additional chemical methods (other than neutralization with $\mathrm{HNO}_{3}$ or $\mathrm{H}_{2} \mathrm{SO}_{4}$ ) for neutralizing or reacting $\mathrm{NaOH}$ in recycle liquors will be sought and demonstrated. Various possible operating modes for the 242-S vacuum evaporator will be tested in laboratory-scale equipment. 


\section{WASTE MANAGEMENT (Contd)}

\section{Solidification with Phosphoric Acid}

$\begin{array}{ll}\text { Project Managers: } & \text { R. C. Roal } \\ & \text { M. H. Campbel1 } \\ & \text { N. L. Harms } \\ \text { Principal Investigators: } & \text { J. S. Buckingham } \\ & \text { D. A. Puryear } \\ & \text { W. P. Metz }\end{array}$

Objective and Scope

The objective of this work is to develop a process to complete the conversion of in-tank solidification recycle liquor to a stabilized salt cake.

Prior Work

Immobilization of recycle liquors by using phosphoric acid to form a solid mass was investigated. Satisfactory solids were obtained from recycle liquor containing less than 55 weight percent water by adding one mole of phosphoric acid for every three moles of sodium (hydroxide plus aluminate) contained in the liquor. The degree of hydration of the solid obtained by this method is dependent on the temperature of the solid. The amount of heat generated by adding phosphoric acid to waste in the 1:3 mole ratio of acid-to-base is 73 kilocalories (kcal) per liter of waste. On cooling, an exothermic phase change occurs at around $55^{\circ} \mathrm{C}$ which releases $8.7 \mathrm{kcal}$ per liter of waste.

\section{Progress During Report Period}

Studies carried out during this report period indicated that physical and chemical properties of phosphate-solidified waste do not change when such waste is irradiated $\left({ }^{60} \mathrm{Co}\right)$ to an exposure of about $10^{9}$ rads. The viscosities of phosphoric acid-solidified waste slurries ranged from eight centipoise $(\mathrm{CP})$ at $90^{\circ} \mathrm{C}$ to $1500 \mathrm{cP}$ at $40^{\circ} \mathrm{C}$; such 


\section{WASTE MANAGEMENT (Contd)}

\section{Solidification with Phosphoric Acid (Contd)}

thixotropic slurries exhibited non-Newtonian properties. Slurries of. recycle liquor and phosphate-solids held at $60^{\circ} \mathrm{C}$ for three to seven days, conditions likely to prevail in a phosphate-solids receiver tank, did not completely solidify when cooled to about $25^{\circ} \mathrm{C}$. Compositions of liquid and slurry phases as a function of acid-to-waste ratios and recycle liquor composition were also determined.

\section{Evaluation of Effort}

Laboratory data generated in this and prior report periods show that addition of phosphoric acid to recycle liquors is not a satisfactory way of solidifying such wastes.

\section{Future Work}

No additional work is scheduled. 
Solidification by the Aqueous Silicate Process

Project Managers:

Principal Investigators:
R. C. Roal

M. H. Campbe11

G. S. Barney

C. H. Delegard

W. P. Metz

Objective and Scope

Using aqueous silicate chemistry, a process will be developed to solidify interstitial and recycle liquids from the evaporatorcrystallizer program.

Prior Work

Reaction of synthetic recycle liquors from the evaporatorcrystallizer program with various bentonite and kaolin clays produced the mineral cancrinite, a salt-filled sodium aluminum silicate. An appreciable amount of base ( $\mathrm{NaOH}$ or sodium aluminate $\left[\mathrm{NaAlO}_{2}\right]$ ) must be present in the waste in order for the reaction to occur. The amount of clay necessary to form a solid product varies from 0.70 gram per milliliter for spray-dried kaolin to $1.30 \mathrm{~g} / \mathrm{ml}$ for a commercial bentonite. The product from kaolin is harder than that from bentonite. The time necessary for the clay-waste reaction to go to completion is about three hours at $100^{\circ} \mathrm{C}$ and about 12 hours at $75^{\circ} \mathrm{C}$. Bulk leach rates for the products in distilled water based on B.E.T. surface area measurements are in the range of $10^{-8}$ to $10^{-7} \mathrm{~g} / \mathrm{cm}^{2}$-day.

\section{Progress During Report Period}

Forty-nine commercially available clays were surveyed for use as process reagents. On the basis of physical properties of cancrinite products obtained from these clays, 14 clays were selected for further study. Criteria used to judge the products made from 


\section{WASTE MANAGEMENT (Contd)}

\section{Solidification by the Aqueous Silicate Process (Contd)}

these clays were: hardness, product $\mathrm{pH}$, volume increase on mixing, and percent of liquid not sorbed by the product. Calcined clays appeared to be more reactive and to give the hardest: products with the smallest volume increases.

Mechanical crushing strength tests were made on cancrinite products from various clays. Strengths of the more durable products proved comparable to that of firebrick. For these hard products, increasing the hydroxide concentration in the feed from 4 to $8 \mathrm{M}$ yielded a weaker product. Likewise, products allowed to dry during the reaction were found to be weaker than those reacted without drying. Use of different clays or lower clay/waste ratios resulted in products with lower mechanical strengths. Thus, the aqueous silicate product can be tailored to any mechanical strength in the range of firebrick to mud.

The thermal stabilities and thermal conductivities of various cancrinite products were measured. When the product was heated to the melting point ( $i 900$ to $1200^{\circ} \mathrm{C}$ ) several changes in composition occurred. An initial loss of zeolitic water was followed by decomposition of trapped nitrate and nitrite salts at $700^{\circ} \mathrm{C}$ A change in the crystal structure to form nepheline occurred at about $600^{\circ} \mathrm{C}$. Thermal conductivities of kaolin-waste reaction products were generally higher than those of products made from bentonite $\left[0.00057\right.$ to 0.0028 and 0.00045 to $0.00189 \mathrm{Cal} / \mathrm{sec}-\mathrm{cm}^{2}$ $\left({ }^{\circ} \mathrm{C} / \mathrm{cm}\right)$, respectively]. 


\section{WASTE MANAGEMENT (Contd)}

Solidification by the Aqueous Silicate Process (Contd)

Aqueous silicate products were made from reactions of synthetic 242-S evaporator slurries with clays. These products were found to have physical properties nearly identical to those obtained from synthetic recycle liquor.

\section{Evaluation of Effort}

Much of the laboratory work necessary for a prototype demonstration of the process has been completed. These data show that solidification of recycle liquor by reaction with clays is a viable alternative to solidification by neutralization with phosphoric acid.

\section{Future Work}

The heat of reaction of clay and waste solutions to form cancrinite will be measured. The radiation stability of cancrinite will also be determined. A quantitative description of the process with variations will be developed.

\section{Reports Issued}

ARH-SA-174 (unclassified), January 1974, G. S. Barney, "Fixation of Radioactive Waste by Hydrothermal Reactions with Clays." 


\section{WASTE MANAGEMENT (Contd)}

Characterization of Waste Tank Salt Cake

Project Managers:

R. C. Roal

M. H. Campbe 11

N. L. Harms

M. J. Kupfer

Principal Investigators:

$V:$ L: Schuelein

J. S. Buckingham.

M. D. Martin

W. I. Winters

Objective and Scope

Tests will be developed to characterize waste tank salt cakes and to identify conditions necessary to form a stable solid.

Prior Work

Analytical techniques and procedures were established to measure chemical and physical properties of waste salt cake. Equipment for receiving, sampling, and analyzing radioactive solids was constructed, but a reevaluation of sampling equipment necessitated a change in receiving and handling equipment. A microcalorimeter was calibrated and tested; the accuracy of the microcalorimeter is \pm 10 percent at five microwatts and \pm 100 percent at one microwatt.

\section{Progress During Report Period}

Salt core sampling equipment has been redesigned to take a core 61 centimeters long and about five centimeters in diameter. The existing facility for receiving core samples has been prepared to handle the longer samples. A spectrophotometric method for the determination of nitrate in salt cake was developed; the method has a detection limit of 100 micrograms and a precision and accuracy of $99.3 \pm 5$ percent. 


\section{WASTE MANAGEMENT (Contd)}

Characterization of Waste Tank Salt Cake (Contd)

\section{Evaluation of Effort}

Analytical procedures are complete. Tentative procedures for receiving and handling salt cake samples have been prepared, but: may be modified when actual cores are received.

\section{Future Work}

Additional equipment will be ordered to receive and break down the longer salt cores. Actual salt waste will be characterized when it becomes available. 
WASTE MANAGEMENT (Contd)

PUBLIC PROTECTION ASSURANCE

Waste Cleanup and/or Immobilization.

Project Managers:

R. E. Isaacson
A. J. Shuckrow
R. L. Dillion

(BNW)

(BNW)

Principal Investigators: L. E. Bruns

K. J. Anderson

W. W. Schulz

S. R. Weil

B. W. Mercer

(BNW)

Objectives and Scope

The objective of these studies is to develop new methods for cleanup or stabilization of radioactively contaminated surface and subsurface soils. The cleanup would follow soil characterization, hazard assessment, and establishment of cleanup criteria for the area. The studies will concentrate initially on.cleanup methods for such surface areas'as the contaminated BC. Crib area (about 20 square kilometers), the B Pond bottoms, U P.ond bottoms, and Z-16 ditch. Work on subsurface soils will be concerned with soil stabilization. Technology will be developed for mechanical movement of soil to. burial grounds (e.g., vacuum removal system), soil sealing, soil packaging, and contaminated soil immobilization.

\section{Prior Work.}

A vacuum cleaner prototype for removal of surficial or buried radioactivity was ordered.

On the basis of information gained from proposals on surface and subsurface affixing tests from grout vendors, work with soil 


\section{WASTE MANAGEMENT (Contd)}

Waste Cleanup and/or Immobilization (Contd)

and affixing agents began. The best possibilities appeared to be AM-9 (a cement grout produced by the Gelco Company) and asphaltic emulsions.

Initial leaching studies of $B C$ Crib area contamination were made with various leachants, including water.

Progress During Report Period

Vacuum cleaner tests have demonstrated that contaminated spots in the $B C$ Crib area could be removed at an estimated rate of two to four acres per day by the six-cubic yard vacuum cleaner prototype. More work is required before the unit is ready for "hot" tests.

The Gelco Company addition of 12,000 gallons of AM-9 to a 100foot deep well beside a waste tank demonstrated that such a grout could be easily added to a well. Tests on the extent of the plane formed by the grout addition and its effectiveness need to be studied.

Well-grouting tests in the 300 Area showed that an asphaltic or asphalt-cement grout may be superior to a cement grout. Tests in a 40-foot-deep, five-foot-diameter caisson showed pressure buildup of $4.0 \mathrm{psig}$ at six feet from the caisson periphery when cement grout was added to wells three feet away from the periphery of the caisson. No pressure buildup was noted at a distance of nine feet from the periphery.

Evaluation of Effort

The vacuum system shows promise for cleanup of small areas (e.g., areas of highest contamination in the $B C$ Crib and around 
WASTE MANAGEMENT (contd)

\section{Waste Cleanup and/or Immobilization (Contd)}

fences, tanks, and buildings). More work on the exhaust system and load-dumping is required to ensure safety to personnel. A test of a larger unit than the prototype is recommended for capacity. studies.

The Gelco grout experiment demonstrated that a grout with the consistency of AM-9 could be easily added via wells. The effective penetration downward of the grout was about three meters; lateral movement needs to be investigated.

Well-grouting tests showed that use of a cement grout may cause some pressure problems to waste tanks. Further tests are necessary to identify optimum grouting materials and to ensure that tank pressurization is not a problem.

\section{Future Work}

The tests on the prototype vacuum system will be completed by the first quarter of FY 1975 and a final report written in the second quarter of FY 1975. Surface soil affixing bench-scale experiments will continue aiong with subsurface grouting experiments. In-field tests are planned on selected surface areas and subsurface volumes.

Initial studies will begin on cleanup and immobilization of pond bottoms. Prototype dredge equipment or equivalent wil1 be surveyed for possible adaptation to pond cleanup: Laboratory tests in conjunction with the pond cleanup will continue: Other associated equipment (solid-liquid separation devices, asphalt-soil extruders, etc.) will also be investigated. 
WASTE MANAGEMENT (Contd)

\section{Migration of Radioactivity into $B C$ Crib Area Soil}

Project Managers:

Principal Investigators:
R. E. I saacson

M. H. Campbel1

W. W. Schulz •

L. E. Bruns

Objectives and Scope

One objective of this work is to determine water leachability of ${ }^{137} \mathrm{Cs}$ and ${ }^{90} \mathrm{Sr}$ from soil in the BC Crib. Another objective is to survey the effectiveness of various chemicals in promoting leachability (forced migration) of ${ }^{137} \mathrm{Cs}$ and ${ }^{90} \mathrm{Sr}$ into the soil.

\section{Prior Work}

Batch leaching tests (24 hours, $25^{\circ} \mathrm{C}$ ) using leachant-to-soil weight ratios of 15 to 20 showed that four leaching agents -- water, $0.1 \mathrm{M}$ solutions of sodium citrate, sodium gluconate, and $\mathrm{NH}_{4} \mathrm{NO}_{3}$ (ammoni um nitrate) -- removed 9.8, 15.0, 16.9, and 20.0 percent, respectively, of the ${ }^{137} \mathrm{Cs}$ initially present on samples of representative surface soil from the $B C$ Crib. Other leachants tested removed $\leq$ three percent of the ${ }^{137} \mathrm{Cs}$. Subsequently, about 50 column volumes of $0.1 \mathrm{M} \mathrm{NH}_{4} \mathrm{NO}_{3}$ were passed downflow (at $25^{\circ} \mathrm{C}$ and one column volume per hour) through 46.7 cubic centimeters (1.9 centimeter diameter) beds of soil taken from the top seven to ten centimeters of the $B C$ Crib. Paralleling to some extent results of the batch leaching tests, the $0.1 \mathrm{M} \mathrm{NH}_{4} \mathrm{NO}_{3}$ solution removed 41 percent of the ${ }^{137}$ Cs originally present on the soil. However, in duplicate tests, 50 column voiumes of water removed only about five percent of the ${ }^{137}$ Cs. 
WASTE MANAGEMENT (Contd)

Migration of Radioactivity into BC Crib Area Soil (Contd)

Progress During Report Period

Leachability of ${ }^{90} \mathrm{Sr}$ from BC Crib surficial soil was established. In batch leachings ( 24 hours, $25^{\circ} \mathrm{C}$ ) at a leachant-to-soil weight ratio of 15 , leachants consisting of water and $0.1 \mathrm{M}$ solutions of $\mathrm{NH}_{4} \mathrm{NO}_{3}$, sodi um gluconate, sodium citrate, and oxalic acid removed 8.6. $47.2,46.7,58.9$, and 42.4 percent, respectively, of the ${ }^{90} \mathrm{Sr}$ present on $B C$ crib soil. In column leaching tests, 50 column volumes each of $0.1 \mathrm{M}$ sodium gluconate, $0.1 \mathrm{M} \mathrm{NH}_{4} \mathrm{NO}_{3}$, and plain water passed downflow (at $25^{\circ} \mathrm{C}$ and one column volume per hour) through 47-cubic centimeter beds of $B C$ Crib soil removed, respectively, 60, 48, and eight percent of the ${ }^{90} \mathrm{Sr}$ initially present on the soil. These results agreed well with results of the batch tests.

\section{Evaluation of Effort}

The objectives of this work have been completed successfully. Both ${ }^{137} \mathrm{Cs}$ and ${ }^{90} \mathrm{Sr}$ sorbed on the BC Crib soil are tightly bound and only slightly water-leachable. However, up to about 50 percent of both the ${ }^{137} \mathrm{Cs}$ ard ${ }^{90} \mathrm{Sr}$ on the soil is readily leachatile by dilute ammoniuri nitrate soilution.

\section{Future Work}

No additional experimental work is planned. A report suminarizing these findings will be prepared. 


\section{WASTE MANAGEMENT (Contd)}

Nondestructive Measurement Instrumentation

Project Manager:

Principal Investigator:

Objective and Scope
M. H. Campbell

W. H. Zimmer

In this program, instrumentation will be developed which will nondestructively and automatically inventory radionuclides for sorting, accounting, and field measurement purposes.

Prior Work

Two generations of Automatic Radioactive Inventory Systems (ARIS-1 and 2), consisting of Chemical Technology Laboratory-specified programs in Tracor Northern, Inc., NS-660 pulse height analyzercomputers, have been procured. The first system, ARIS-1, has already been used to automatically analyze bulk environmental samples such as vegetation, soil and water samples, low-level crib and tank leak soil cores, and large air filter samples. Two detector sys tems were developed to analyze such samples: One system consists of three $\mathrm{Ge}(\mathrm{L} i)$ detectors with 10 percent relative efficiency in a box array. The second system, primarily used for analyzing environmental samples, consists of an 88-cubic centimeter coaxial Ge(Li) detector with a 24-centimeter diameter by 30.5 centimeter high $\mathrm{NaI}(\mathrm{Tl})$ Compton suppression guard detector.

\section{Progress During Report Period}

Automatic Radioactive Inventory System-2 (ARIS-2) equipment has been ordered and delivery is imminent; ARIS-2 is programmed to accomplish the following tasks, which are beyond the capabilities of ARIS-1.

- Calculate gamma and bremsstrahlung activity, with or wi thout decay time correction. 


\section{WASTE MANAGEMENT (Contd)}

Nondestructive Measurement Instrumentation (Contd)

- Apply a geometry function (as opposed to a factor).

- Apply a correction for internal (source) sorption from photon cross section tables.

- Apply correction for an external sorber from photon cross section tables.

- Test for the presence or absence of a photo-peak on the basis of individual precision.

- Calculate detection limits for any photo-peak in any source spectrum.

- Type report-formatted results.

- Write or search for calibration tables on cassette magnetic tape.

The ARIS- 1 and -2 units are equipped to receive spectral data on cassette magnetic tape and to function as central data reduction centers. These units will be combined with a Tracor Northern NS-880 pulse height analyzer-computer which is oriented to X-ray analysis. The combined system is known as the Gamma, X-Ray Data Reduction (GXDR) system. Data are generated on inexpensive, hardwired pulse height analyzers with cassette magnetic tapes as their sole peripheral output. These satellite systems follow the detectors. to data collection sites.

New detector systems developed or being developed include a down-looking $\mathrm{Ge}(\mathrm{L} i)$ detector with a conical shield which defines $0.1 \mathrm{~m}^{2}$ of soil surface for in situ analysis. The system has been received and calibrated and is now ready for use in the mobile laboratory Dev-Van I. Two low-energy coaxial Ge(Li) detectors have been procured to analyze well cores in mobile laboratory Dev-Van-II. The collimator assembly is being fabricated. 


\section{WASTE MANAGEMENT (Contd)}

\section{Nondestructive Measurement Instrumentation (Contd)}

A replacement system for the environmental level Anti-Compton detector system has been designed and components ordered. The new system will consist of two 20 percent relative efficiency, 44:1 peakto-Compton, $\mathrm{Ge}(\mathrm{L} i)$ detectors operated face-to-face in a $24-\mathrm{cm}$ diameter by $30.5-\mathrm{cm}$ high annulus compton suppression guard detector. It is anticipated this detector will improve detection capabilities by a factor of five over the present system.

Two well-sonde detector systems for the mobile laboratory Dev-VanI I have now been designed and ordered. Both of these detectors will operate inside a $10-\mathrm{cm}$ diameter hole, at depths up to 150 meters, 30 meters of which may be under water. Both sondes will be used for analysis of pond bottoms. One sonde will contain a 12. percent relative efficiency $\mathrm{Ge}(\mathrm{Li})$ detector for annular, high sensitivity, gamma energy analysis. The other will contain a one- $\mathrm{cm}^{3}$ intrinsic germanium detector for low sensitivity and collimated analysis.

One additional system for mid- to high-range energy analysis has been designed and ordered. It consists of a 15 percent relative ' efficiency, 45:1 peak-to-Compton, primary Ge(Li) detector in a collimated, Anti-Compton, off-center well, $\mathrm{NaI}(\mathrm{Tl})$ detector. The source activity range of this detector system will be $10^{-6}$ to $10^{2}$ curies for high specific activity emitters; it will have a peak-toCompton ratio of approximately 500:1.

\section{Evaluation of Effort}

The design stage for both data reduction systems and detector systems has been completed and the systems procured. The potential of a central data reduction system (GXDR) and satellite acquisition 


\section{WASTE MANAGEMENT (Contd)}

Nondestructive Measurement Instrumentation (Contd)

systems has been evaluated and exceeds all expectations. "The detector system already delivered operate within or own design specifications.

Future Work

All systems procured but not received to date will be calibrated and placed in service. The ARIS- 1 is to be made a hardware twin to ARIS-2 so that either custom program can be run, depending on application needs. Future developments will be directed at lowering the detection level of transuranic emitters and at trace elemental analysis with $X$-ray fluorescence and activation analysis. 
WASTE MANAGEMENT (Contd)

\section{Environmental Instrumentation}

Project Managers:

Principal Investigators:
R. E. Isaacson

J. H. Jarrett

R. W. Perkins

L. E. Bruns

W. H. Zimmer

R. G. Oliver

S. R. Weil

O. H. Koski

H. G. Rieck

R. T. Brodaczynski
(BNW)

(BNW)

(BNW)

(BNW)

(BNW)

Objective and Scope

The objective of these studies is to develop instrumentation and auxiliary equipment for field use that will accurately and rapidly characterize the amount, type, and distribution of radionuclides on soil surfaces and within soil samples. Wherever possible; instrumentation will be developed that can assay the radionuclides in situ, both in contaminated ground surfaces and in buriat grounds.

\section{Prior Work}

After literature study and trips to other atomic energy sites, initial environmental instrumentation was proposed. Equipment such as a magnetometer, an environmental neutron counter, a millirad per year sensitive gamma dosimeter, and a directional $\mathrm{Ge}(\mathrm{Li})$ in situ gamma monitor for assaying contaminated ground surfaces were ordered, received and prepared for use. Most of the equipment will be installed in mobile laboratory Dev-Van-I for field use.

other equipment ordered and received included a thin-window $\mathrm{NaI}(\mathrm{Tl})$ gamma monitor, electronics for the mobile laboratories, two $\mathrm{Ge}(\mathrm{L} i)$ in-van detectors (for profiling cores), two battery-operated, 


\section{WASTE MANAGEMENT (Contd)}

\section{Environmental Instrumentation (Contd)}

easily portable $\mathrm{NaI}(\mathrm{TH})$ in-field monitors, and instrumentation for automating resuspension systems in the field.

Progress During the Report Period

A directional neutron counter was devised for measuring the flux on the Z-9 Trench floor. Another neutron counter was tested for environmental assaying. The Z-9 Trench flux showed no high buildup areas at any place on the floor. Copper wafers were placed in the Z-9 Trench to check the neutron flux and neutron dose rate. The environmental neutron counter was able to detect plutonium-containing areas at the $U$ Pond and $P-11$ (old critical mass testing building).

A neutron survey taken from a helicopter showed the presence of a significant amount of plutonium when flying over the 234-5 Plutonium Finishing building, but only background radiation over the $U$ Pond.

An argon-filled sphere ionization chamber was tested in many areas throughout Hanford. "The BC Crib area averaged 500 to 700 millirads per year in the more concentrated zones. The $U$ Pond shore areas often exceeded 1.3 rad per year, the upper range of the instrument. The 300- $\mathrm{Y}$ and $300-\mathrm{N}$ burial gardens showed only background radiation.

Other tests were made of new equipment, including an initial magnetometer test at a transuranic burial ground and shakedown tests of an alpha water analyzer, which is sensitive to about 0.1 MPC.

Equipment for planned mobile laboratory Dev-Van-I was calibrated. The directional $\mathrm{Ge}(\mathrm{Li})$ gamma system proved able to detect nanocuries of ${ }^{137} \mathrm{Cs}$ and ${ }^{241} \mathrm{Am}$. Other equipment destined for Dev-Van-I consisted of a neutron counter, portable $\mathrm{NaI}(\mathrm{Tl})$ gamma monitors, and a magnetometer. 


\section{WASTE MANAGEMENT (Contd)}

\section{Environmental Instrumentation (Contd)}

Instrumentation for Dev-Van-II has been ordered and.some of the electronic gear is on-site. The van-mounted $\mathrm{Ge}(\mathrm{L} i)$ detectors have been received. Dev-Van-II will eventually have the capability of assaying cores in the field and will be able to assay or profile certain radionuclides in-tank and in-well.

Initial basic research on beta and $\mathrm{Pu}$ environmental monitors began; two systems for Pu appeared feasible -- X-ray and neutron monitoring.

\section{Evaluation of Effort}

The argon gamma dosimeter is satisfactory for dose characterization and has been recommended for routine environmental characterization use. The neutron directional counter appears feasible and an invention report has been processed. More refinements such as optimum moderation and cadmi um, improved $\mathrm{BF}_{3}$ tubes (low gamma sensitivity), and improved calibrations are needed to improve the sensitivity and accuracy. The copper wafers placed in the Z-9 Trench over one- to four-day periods corroborated the results obtained by the directional counter.

The environmental neutron detector will require a more neutronsensitive, less gamma-sensitive $\mathrm{BF}_{3}$ probe and calibration with lowlevel standards to extend the quantitative detection range below the milligram per liter range.

During magnetometer studies in the transuranic burial garden, definite variations of the magnetic flux were noted. These results must be interpreted. 
WASTE MANAGEMENT. (Contd)

\section{Environmental Instrumentation (Contd)}

Initial equipment procured and tested for Dev-Vans-I and -I is operating satisfactorily after a number of calibrations and field tests.

Future Work

During fiscal year $19 \% 5$ a final report will be issued on the sensitive (millirad per year) gamma dosimeter; the neutron counter for field use will be evaluated; and a final report on the directional seutron counter will be issued. Tests will continue on the magnetometer. Tests will begin on the NaI portable in-field gamma monitors and on the alpha water monitor using a special powder as the scintillant. Special thermal luminescent dosimeters (TLD's) will be obtained for in-field and in-pond dosimeter studies, and water studies are planned to profile plutonium in waste tanks.

Dev-Van-I will be obtained, equipment will be installed, and initial in-well tests will be made. If possible, Lev-Van-II will be obtained and initial instrumentation will be installed.

Instrumentation for resuspension systems will be further automated and simplified. Tests will be initiated on conceptual instrumentation for in-field measurement of the radionuclide buildup on filters.

Work will continue on the feasibility of low-level beta and plutonium in situ analyzer. A 55-gallon drum counter that may detect ten nanocuries of plutonium will be evaluated. 
WASTE MANAGEMENT (Contd)

Environmental Instrumentation (Contd)

A californium in-well activation system is planned for initial feasibility studies in FY 1975. A two-milligram source has been requested and a 0.6-milligram source is available from BNW for first tests. 


\section{WASTE MANAGEMENT (Contd)}

Waste Characterization

Project Managers:

R. E. Isaacson

L. C. Schwendiman

Coordinating Engineer: L. E. Bruns

Principal Investigators: W. W. Schulz

S. R. Weil

J. Mishima

G. A. Sehmel

W. C. Weimer

$(\mathrm{BNW})$

(BNW)

Objectives and Scope

This program will identify the locations, the physical and. chemical properties, and the means by which radionuclides at Hanford can enter.man's environment. The characterization studies will be limited to the 200 Area plateau and will consider movement of radionuclides as a result of meteorological and biological driving forces.

Prior Work

After initial sample results were received, mainly from the $B C$ Crib and $U$ Ponds, cooperative effort between ARHCO and the Division of Environmental and Biomedical Research (DEBR) programs was initiated to assay aquatic organisms and pond bottoms. A successful helicopter aerial survey was made of eight different areas and the routine application of this assaying device was turned over to Quality Assurance. Resuspension studies began at $U$ Pond and BC Crib.

Studies were initiated to determine the distribution and . potential for release of surficial contamination in the 200 Areas plateau and environs. Computer programs were developed and fieldtested for objective wind field analysis and wind field trajectory 
WASTE MANAGEMENT (Contd)

Waste Characterization (Contd)

construction. Computer display programs were started. The feasibility of balloon tracing by aircraft was demonstrated.

Reactions of various combinations of salt cake waste and other materials expected to be in the tanks were simulated in theory and various mixtures of anion exchange resin and simulated salt cake were studied for exotherms. Hazard index studies were conducted using two separate computer programs on N. Reactor fuel processing wastes, power reactor fuel processing wastes, individual waste tanks, and other waste entities.

Progress During Report Period.

- Initial efforts have concentrated on the $B C$ Crib and $U$ Pond areas. About $500 \mathrm{U}$ Pond analyses have been received in the DEBR/ARHCO programs, including plutonium and americium concentrations in organisms and pond bottoms and initial chemical and physical properties of the actinides in the pond bottoms. Further samples of contaminated surface materials have been collected from the area around $U$ Pond to characterize the distribution of radionuclides in this area.

The distribution of ${ }^{137} \mathrm{Cs}$ in contaminated surface materials of the $B C$ control area was characterized and reported. Engineering scale experiments to determine the airborne release of ${ }^{137} \mathrm{Cs}$ from contaminated surface materials involved in a fire and from the solid residues were also completed. Preliminary results indicate fractional release of ${ }^{137} \mathrm{Cs}$ during heating of contaminated surface materials to $200^{\circ} \mathrm{C}$ is small $\left(<10^{-2}\right.$.

Installation of equipment and instrumentation at both $U$ Area and $B C$ Area now permits automatic air sampling as a function of three 
WASTE MANAGEMENT (Contd)..

Waste Characterization (Contd).

wind speed increments, wind direction, and sampling heights. Results indicate that $U$ Area and some other sources must be sites for airborne radioactivity. Five tower filter samples have been analyzed to date by total dissolution techniques and subsequent analysis. Positive results for $U$ Area were obtained for ${ }^{239-240} \mathrm{Pu},{ }^{238} \mathrm{Pu}$, and ${ }^{241} \mathrm{Am}$. All airborne concentrations have been far below. MPC air for occupational exposure.

Computer display programs which permit rapid and meaningful interpretation of flow patterns and air trajectory plots were completed and tested. The programs have demonstrated the unreliability. of air trajectories using a single wind point at distances greater than a few kilometers downwind of the source. A computer model for estimating the diffusion of airborne contaminants has been adapted for use by local computers.

A study was initiated to evaluate the frequency and potential significance of the resuspension of contaminated soil and debris by winds and dust devils. Analysis of historical meteorological data indicated that conditions were most favorable for the formation of dust devils in excess of 400 feet during the mid-afternoon of approximately 91 percent of Juily.

Characterization studies were also made of other areas. In the Redox swamp areas, including the ditch, ring and 30-centimeter-deep core samples were taken. Results were obtained from various sources on cesium, americium; strontium, plutonium, and other "radionuclides. Some Gable Mountain pond bottom assays were made in conjunction with the biological programs. 


\section{WASTE MANAGEMENT (Contd)}

\section{Waste Characterization (Contd)}

A leak detection test site, simulating an idealized waste tank and consisting of 33 wells, 30, 40, and 50 feet deep, was constructed. Leak detection systems in the test area were conducted by the Boeing Aerospace Corporation, Battelle-Northwest, and Holosonics, Inc., using soil conductivity, high radio frequency, and acoustical sensing systems. The Boeing system, which encompassed the complete tank area, detected center-of-the-tank and side-tank $3 \mathrm{MNNO}_{3}$ and water leaks readily; $B N W$ used impedance-resistivity measurements between individual sensor wells to simulate the tank with favorable results. The Holosonics approach needs further engineering study.

The hazard index study on the toxicity of the elements being performed by BNW indicates that after about $10^{8}$ years lead appears to be more toxic than plutonium.

\section{Evaluation of Effort}

Combinations of aerial surveys, field monitoring by various instruments, representative soil sampiing and laboratory analyses have demonstrated that radionuclides in diverse areas such as the $B C$ Crib, $U$ Pond and the $Z$ trenches can be determined and characterized. The information from the $B C$ Crib analyses, along with chemical and physical property data of the radionuclides has aided in understanding how radionuclides from a surficial contamination can enter into man's ecosystem.

The computer display models for simulating the downwind transport of resuspended radioactivity have already proven to be of value, indicating the inadequacy of single wind sources for estimating wind trajectories and the need for additional analysis to establish a climatology of trajectory patterns by release periods and seasons. 


\section{WASTE MANAGEMENT (Contd)}

\section{Waste Characterization (Contd)}

Tests on an idealized simulated waste tank system indicated that the use of conductivity, resistance and/or capacitance measurements to detect leaks around'waste tanks is feasible. The test site data extrapolated to actual tank farm conditions show that a leak sensitivity of 250 gallons from the center of a tank and a 100-gallon leak sensitivity from the side of a tank may be possible.

\section{Future Work}

Further measurements will be made in the $B C$ Crib area using nondestructive in situ assay equipment and further representative sampling and laboratory analyses. An interim report wiil be issued on the characterization of the $B C$ Crib. The cooperative program with the DEBR and ARHCO on a study of Pu-Am buildup in aquatic organisms will continue. Atlantic Richfield Hanford Company will issue an interim report on the work done on $U$ Pond and its relation to current and long-term waste management of the area.

Evaluation of the fractionai airborne release of surficial contamination during heating and during manipulation of the soii during decontamination operations will be concluded. An experimental. prograin to evaluate the release of stored, solid, interim high-level waste (salt cake) will be initiated.

Field resuspension research using upwind and downwind tower arrays wi 11 continue at $U$ Area and $B C$ Area and wi 11 be expanded to include B Swainp and other areas. Seasonal variations in resuspension will be determined. The experimental sampling arrays and selection of wind speed increments will be modified on the basis of radiochemical results that are received. Resuspension data will be incorporated into a downwind transport model for BC Area. 


\section{WASTE MANAGEMENT (Contd)}

\section{Waste Characterization (Contd)}

Work will continue to determine the transport and dispersion of radioactive farticles from unplanned and long-term releases. Development of air drainage model based on local topography, refinement of the transport diffusion model for distances beyond ten kilometers, and establishment of a reliable representative wind network to provide real time data will be undertaken for the arcidental release sector. Work in the long-term release area will concentrate on analyzing historical wind and temperature data of at least a year's duration to provide an interim assessment of the impact of long-term releases. The assessment will be modified as more reliable and representative results become available. A topical report will present the data from the dust devil literature review and analysis of currently available historical meteorological information. Several alternate approaches will be evaluated to provide a more precise evaluation of the impact of dust devils on the resuspension of contaminated materials.

Tests of detection systems for outside-the-tank and pipe leaks will be concluded in the first part of FY 1975. A decision will be made for using the Boeing and/or the BNW systems by October 1974 .

A hazard index report will be published in the first quarter of FY 1975. An interim report on hazardous reactions of high-level waste salt cake will be issued in FY 1975.

Reports Issued

ARH-SA-184 (unclassified), January 21,1974, L. E. Bruns and S. R. Weil, "Directional Neutron Flux Survey of Actinide Waste Trench." ARH-SA-176 (unclassified), March 1974, L. E. Bruns, "Aerial Gamma Survey by Helicopter to Measure Surficial Contamination." BNWL-1850 Pt. 3 (unclassified), August 1973, L. L. Wende 11 and W. F. Sandusky, "Mesoscale Transport and Diffusion Studies." 


\section{WASTE MANAGEMENT (Contd)}

\section{WASTE TANK LEAK DETECTION AND PREVENTION}

\section{Waste Tank Liquid Level Monitoring System}

Project Managers: $\quad$ R. E. Is aacson

R. C. Roal

Coordinating Engineer: L. E. Bruns

Principal Investigators: R. G. 01iver

H. F. Jensen

Objectives and Scope

This program consists of two phases. The first part is an audit program which will analyze the effectiveness of the current liquid level monitoring system with respect to possible design and/or operational deficiencies. The program involves a system engineering analysis, an instrument qualification test, and a design review. intended to pinpoint problem areas. A11 components, including the Fruit Industries Corporation (FIC) instrument electronics, data acquisition system, mechanical system, sensor, computer program, and data report, will be analyzed. The second phase of the program involves the review and development of improved means for determining liquid levels in the waste storage tanks.

Prior Work

An engineering audit of the present liquid level measurement system (FIC gage) and data transmission system was completed and documented by BNW personne1. Different methods of monitoring liquid level were investigated, and from this study a radio frequency absorption type and an ultrasonic log concept were selected for more detailed examination. 


\section{WASTE MANAGEMENT (Contd)}

\section{Waste Tank Liquid Level Monitoring System (Contd)}

The preliminary effort, which investigated whether a radio. frequency liquid level system could be used for the measurement of liquid level (disregarding effects such as temperature, pressure, and fluid composition), showed that a reasonable sensitivity estimate for the unit is about $4 \times 10^{-3}$ inches in a 60 -foot span. The following effects on the accuracy of the system were observed during the tests: (1) Variation of the conductivity of the liquid from tap water to saturated sodium nitrate produced about a 10 percent change in output. (2) Air bubbles in the antenna changed the reading of the system by 0.1 percent. (3) Addition of dry sodium nitrate to a saturated solution produced effects markedly different from the liquid when the salt level was below the antenna end, but similar to liquid when the salt level was above the antenna end.

Experiments using a six-inch glass tank with an external ground plane, a six-inch stainless-steel tank, and a one-half-inch tank (pipe) as well as a study of temperature effects and liquid conductivity suggested that the workable system analog may be capacitance for the wetted air of the probe or antenna and a capacitance shunted resistance for the liquid phase.

The ultrasonic log concept is based upon expected differences in the acoustic impedance and acoustic velocity characteristics of the materials in the waste storage tanks. In laboratory evaluation of the system, a pair of cylindrical transducers mounted in steel pipe were used to transmit ultrasonic signals across a water path in a simulated waste tank. Phase angle and peak amplitude measurements on the received signals were obtained for the cylindrical transducer system. Early. results indicated that phase and amplitude changes caused by the presence of foreign materials in the water path between probes can be detected. 


\section{WASTE MANAGEMENT (Contd)}

\section{Waste Tank Liquid Level Monitoring System (Contd)}

\section{Progress During the Report Period}

A periodic review of maintenance logs on the FIC system continued. Laboratory evaluation of new "detente" counters revealed that a degree of contact "bounce" can occur at the wiper contacts which present data to the level transmitter boards, possibly resulting in some data inaccuracy.

In the radio frequency liquid level system monitoring device, a test of a probe configuration which greatly increased the capacitive impedance resulted in a lower temperature coefficient, better linearity, and greater insensitivity to liquid conductivity, but at the expense of sensitivity. Sensitivity was, however, several. magnitudes better than required for an acceptable system.

A test using this probe with an air gap of about 0.070 inches between the probe wire and the concentric housing gave a sensitivity of 600 frequency units per inch with a projected span of 500 inches of Tiquid. Composition variation in the liquid phase from tap water to $4 M \mathrm{NaNO}_{3}$ and saturated $\mathrm{NaNO}_{3}$ showed no appreciable effects. Temperature effects, however, became appreciable above $125^{\circ} \mathrm{F}$. Dimensional changes in the polyethylene outer probe cover may be responsible. Voltage supply variations from 100 to 150 volts at $60 \mathrm{HZ}$ also showed no short-term effects on the output.

UTtrasonic impedance and attentuation measurements made on simulated wastes indicate that although liquid wastes are slightly weaker transmitters of ultra-sound than water, there should be no significant problem in transmitting ultra-sound through the liquid waste over reasonable distances (10 to 15 feet). Ultrasonic attenuation measurements have also been made on simulated salt cake 
WASTE MANAGEMENT (Contd)

Waste Tank Liquid Level Monitoring System (Contd)

with laboratory test apparatus. A four-inch-thick layer of salt was used to simulate salt cake buildup on the wet well probes. Although the salt cake material weakened the signal significantly, even more than the liquid waste material, a useful ultrasonic signal could be transmitted. These measurements will be used for determining the transmitter pulse power requirements for the demonstration model of the ultrasonic logging system.

Future Work

The final report on the engineering audit will be completed and issued. The effects of other variables pertinent to the successful application of the radio frequency liquid level system monitoring devices will be studied, particularly the effects of a two-phase system in the proximity of the probe (antenna), and geometry of the probe and ground plane. Also, tests using decreased probe sensitivity and with improvements in temperature coefficient and linearity will be conducted. A demonstration unit will be constructed and tested.

A demonstration unit for the ultrasonic log concept will be constructed and tested. 


\section{WASTE MANAGEMENT (Contd)}

Waste Tank Integrity

Project Managers: R. E. Isaacson

R. C. Roal

Coordinating Engineer: L. E. Bruns

Principal Investigators: R. F. Maness (BNW)

E. L. Moore

Objectives and Scope

The objectives of this project are to identify tank failure mechanism and to develop methods for determining imminent tank failure and for increasing useful tank 1ife.

Various forms of corrosion will be investigated to define failure mechanisms. Methods for detecting tank failure will include both photography and nondestructive testing techniques such as electromagnetic acoustic ultrasonic attentuation and velocity measurements; acoustic emission analysis; magnetic perturbation analysis; and pulse echo ultrasonics in conjunction with a magnetic crawler.

Cathodic protection will be examined as a technique for extending useful tank life.

Prior Work

Pre-cracked mild-steel c-ring coupons and weldment coupons were used to'study stress corrosion cracking (SCC) in nitrate solutions. Time-to-failure was evaluated as a function of nitrate concentration, temperature, and sulfate concentration. Cracking occurred at all concentration levels evaluated at boiling temperatures, while the time-to-failure increased from a few hours to about one week as the nitrate concentration decreased from 10 to 0.05 molar. In tests at 60,80 , and $90^{\circ} \mathrm{C}$, SCC occurred at $80^{\circ}$ and $90^{\circ} \mathrm{C}$ in four days or less, whereas SCC did not occur after five months' exposure at $60^{\circ} \mathrm{C}$. 
WASTE MANAGEMENT (Contd)

\section{Waste Tank Integrity (Contd)}

The effect of adding about $0.5 \mathrm{M}$ sulfate to boiling $5 \mathrm{M} \mathrm{NaNO}_{3}$ solution was to inhibit completely SCC of as-fabricated weldments. The effect of sulfate addition on SCC of pre-cracked C-rings was to increase time-to-failure.

The corrosiveness of simulated high-level solidified waste to carbon steel was evaluated. Variables included caustic content, water content, and temperature. In addition, corrosion tests were made with waste prepared from solutions in which about 90 percent of the caustic content had been neutralized with either phosphoric; sulfuric, or nitric acid. At the end of seven months, exposure corrosion rates in the unneutralized waste ranged from 0.5 to 2.6 $\mathrm{mi}$ ls per year. Pitting occurred in all cases. The corrosion rates in the partially neutralized was te were $<0.1 \mathrm{mil}$ per year with no pitting. No SCC was found in any cases.

In the future the caustic content of alkaline high-level waste may be partially neutralized prior to in-tank solidification. Thus, determinations were made of the corrosiveness of solutions which exist in equilibrium with "standard" waste and in similar solutions containing decreasing ( 6 to 1 M) amounts of caustic. The corrosion rate of mild steel in these solutions as determined by Corrator probes and by weight loss varied from 0.5 to $0.1 \mathrm{mils}$ per year, depending upon the caustic content. These rates are about ten-fold lower than those obtained in solidified waste containing 5 to 15 percent excess water.

Progress During Report Period

Concentration cells which could be established in alkaline highlevel waste are being evaluated as a cause of localized attack of 


\section{WASTE MANAGEMENT (Contd)}

\section{Waste Tank Integrity (Contd)}

mild steel. Voltage measurements on mild-steel coupons immersed in air-free and in air-sparged $6 \mathrm{M} \mathrm{NaOH}$ solutions at $90^{\circ} \mathrm{C}$ indicated an ennobling effect of about 100 millivolts as a result of the air sparge. Cells produced by immersing mild-steel electrodes in concentrated versus dilute $\mathrm{NaOH}$ and $\mathrm{NaOH}-\mathrm{NaNO}_{3}$ versus $\mathrm{NaOH}\left(\mathrm{all}\right.$ at $90^{\circ} \mathrm{C}$ ) were found to be of little or no consequence. Attempts to produce preferential attack of mild steel at the liquid-vapor interface in air-sparged simulated alkaline high-level waste solution were not successful. General corrosion and pitting attack in the vapor phase was accelerated as a result of the air sparge, whereas attack in the liquid phase was inhibited.

The corrosiveness of Hanford high-level radioactive waste is reduced by the presence of the nitrite produced by the radiolytic decomposition of nitrate. Nitrite reduces the corrosiveness of aqueous solution by inhibiting the anodic reaction and is, therefore, classified as a dangerous inhibitor since nitrite concentrations less than that required for complete protection may produce severe pitting or crevice attack. Loss of nitrite may occur through an oxidation-reduction reaction or simply by dilution. The effect of a large dilution of high-level waste solution on mild-steel corrosion was determined by exposing mild-steel specimens to dilute salt solutions containing six levels of nitrite in the range 0.1 to $\mathrm{OM}$. Three solution compositions were used, all at pH 9.5: (1) $0.01 \mathrm{M}$ $\mathrm{NaNO}_{3}-0.1 \mathrm{M} \mathrm{Na}_{2} \mathrm{SO}_{4}$, (2) $0.01 \mathrm{M} \mathrm{NaNO}_{3}-0.05 \mathrm{M} \mathrm{Na}_{2} \mathrm{SO}_{4}$, and (3) $0.05 \mathrm{M} \mathrm{Na}_{2} \mathrm{SO}_{4}$. The solution containing sulfate only was evaluated because Savannah River Laboratory data indicate sulfate greatly enhances pitting attack. A Teflon 0-ring produced a crevice on all the corrosion specimens. Specimens were exposed at $25^{\circ}$ and $60^{\circ} \mathrm{C}$ for 325 hours. 


\section{WASTE MANAGEMENT (Contd)}

\section{Waste Tank Integrity (Contd)}

Pitting and crevice attack occurred in the nitrate-bearing solutions at $25^{\circ} \mathrm{C}$ at nitrite concentrations of $10^{-3}$ and $10^{-2} \underline{\mathrm{M}}$. No pitting or crevice attack occurred at higher or lower nitrite concentrations. In the sulfate solution, pitting and crevice attack occurred at nitrite concentrations of $10^{-2}$ and $10^{-1} \mathrm{M}$. At $60^{\circ} \mathrm{C}$ the range of pitting included nitrite concentrations from $10^{-5}$ to $10^{-1} \underline{\mathrm{M}}$. Penetration during the test period ranged from about 3 to $10 \mathrm{mils}$. Similar tests were made with concentrated salt solutions representing the liquid phase in equilibrium with Hanford solidified waste. No preferential attack has been observed to date ( 300 exposure hours) regardless of the nitrite concentration 0.0 to $1.0 \mathrm{M}$ ).

Mild-steel specimens cathodically protected in simulated solidified waste were examined after 1850 exposure hours. Exposures were in a waste containing 15 percent excess water at $85^{\circ} \mathrm{C}$; current densities were $2.5,5.0$, and 10 milliamps per square foot. The specimens exposed to current densities of 2.5 and 5.0 milliamps per square foot corroded at rates of 1 to $2 \mathrm{mils}$ per year as evidenced by weight loss. However, pitting attack was rather severe ( 5 mil penetration) in both cases. The specimen exposed to a current density of to milliamps per square foot evidenced no pitting attack and corroded at a rate of 0.8 mils per year as determined by weight loss, indicating the minimum protective current density lies between 5 and 10 milliamps per square foot. The data will be discussed with a specialist in cathodic protection engineering regarding the feasibility of cathodically protecting Hanford underground tanks subsequent to in-tank solidification. 


\section{WASTE MANAGEMENT (Contd)}

\section{Waste Tank Integrity (Contd)}

Excellent progress has been made on developing special ultrasonic needle probes which can locate cracks fully penetrating the waste tank walls. These special probes require no liquid couplant and provide a rapid assessment of the tank integrity. The breadboard electronic system associated with the test system is being assembled. Evaluation of Effort

Evaluation of the potential for rapid localized attack of mild steel caused by concentration cells in simulated alkaline highlevel waste indicated that this should not be a cause of premature failure of the waste tank liners. The effect of nitrite in reducing crevice and pitting attack of carbon steel exposed to both simulated solidified high-level waste and the liquid phase in equilibrium with the solidified waste was found to be both concentration and temperature dependent in the solidified waste; the presence of sulfate reduced $i$ ts effectiveness in preventing attack. No preferential attack was observed in the equilibrium liquid phase regardless of nitrite concentration.

An ultrasonic needle probe has proved successful in locating cracks which fully penetrate waste tank walls.

Future Work

Corrosometer probes which have no sensing element-probe interface will be obtained and evaluated. Corrosion probes (Corrosometer and Corrator) will be evaluated in-tank.

Studies of corrosion of the mild-steel tank liners in contact with salt cake will continue. 
DISTRIBUTION

Number of Copies.

Battelle Pacific Northwest Laboratories

E. I. Alpen

R. E. Burns

N. E. Carter

D. L. Condotta

L. C. Counts

D. J. Dau

R. L. Dillon

J. R. Eliason

J. W. Finnigan

R. F. Foster

J. J. Fuquay

J. H. Jarrett

R. E. Nightingale

D. E. Olesen

A. M. Platt

W. H. Rickard

L. C. Schwendiman

A. J. Shuckrow

C. L. Simpson

W.G.N. Slinn

H. H. Van Tuyl

B. E. Vaughn

R. E. Wildung

R. K. Woodruff

United Nuclear Industries, Inc.

W. M. Mathis

N. R. Miller

245

U. S. Energy Research and Development Administration Technical Information Center; Oak Ridge, TN

U. S. Energy Research and Development Administration, Richland Operations Office

O. J. Elgert (14)

R. M. Poteat

H. D. Smith 
DISTRIBUTION (continued)

Number of Copies

H. B Babad

G. E. Bàckman

G. S. Barney

E. W. Bartlett, Jr.

D. G. Bouse

D. E. Braden

L. I. Brecke

D. J. Brown

L. E. Bruns

J. S. Buckingham

C. H. Delegard

D. A. Dodd

J. Faulhaber

R. E. Felt

R. D. Fox (2)

R. G. Geier

R. E. Gephart

N. I. Harms

W. M. Harty

H. H. Hopkins, Jr.

R. E. Isaacson

H. F. Jensen

L. M. Knights

M. J. Kupfer

C. W. Malody

T. R. McKenzie

E. L. Moore

G. A. Nicholson

G. C. Oberg

R. G. Oliver

J. V. Panesko

S. M. Price

W. H. Price

D. A. Puryear

D. C. Roal

V. L. Schuelein

W. W. Schulz

H. P. Shaw

R. M. Smithers

G. T. Stocking

C. P. Sutter

$\mathrm{J}$. H. Warren 


\section{DISTRIBUTION (continued)}

Number of . Copies

Atlantic Richfield Hanford Company. (continued)

W. I. Winters

D. D. Wodrich

W. H. Zimmer

ARHCO Document Services (3)

Central File

Extra (15) 